\title{
Antioxidant and anti-inflammatory effects of red garlic compositions
}

\author{
Min Jung Kang, Dong-Gyu Kim, Jung Hye Shin* \\ Namhae Garlic Research Institute, Namhae 52430, Korea
}

\section{홍마늘 조성물의 항산화 및 항염증 효과}

\author{
강민정 · 김동규·신정혜* \\ (재) 남해마늘연구소
}

\begin{abstract}
Garlic (Allium sativum L.) and traditional herb has several functional properties and strong biological activities, making it useful as a functional food material. We investigated the antioxidant and anti-inflammatory activity of mixed compounds from red garlic and supplementary materials, including ginger (Zingiber officinale Roscoe), doraji (Platycodon grandiflorum), quince (Chaenomeles sinensis), citrus peel (Citri Pericarpium), and mint (Mentha arvensis). The extracts were prepared with water (W) and ethanol (E) at $70^{\circ} \mathrm{C}(\mathrm{W}-70, \mathrm{E}-70)$ and $95^{\circ} \mathrm{C}$ (W-95, E-95) for $3 \mathrm{~h}$. The total content of phenolic compounds was the highest in E-70 $(608.60 \mathrm{mg} / 100 \mathrm{~g})$. Alliin, one of the active ingredients in red garlic, was contained at 1.18-1.29 $\mathrm{mg} / \mathrm{g}$ and $0.81-0.85 \mathrm{mg} / \mathrm{g}$ in water and ethanol extract, respectively. Another active ingredient of red garlic, S-allyl-cysteine (SAC) had higher content in the water extract than in the ethanol extracts. DPPH radical scavenging activity was higher in E-70 (15.96-73.65\%) at 313-5,000 $\mathrm{\mu g} / \mathrm{mL}$. ABTS radical scavenging activity was also higher in E-70 (5.71-77.19\%) than in the others. The ROS production rate showed the same tendency as the NO production, with more efficacy in E-95. The expression level of iNOS and IL-1 $\beta$ was decreased in the E-95 significantly at the concentration of $1,000 \mu \mathrm{g} / \mathrm{mL}$ compared to the lipopolysaccharide (LPS) treated group. Based on the above results, the antioxidative and anti-inflammatory activities of the extracts of red garlic and supplementary materials were expressed by different useful substances. The contents of these useful substances were different according to the extraction solvent and temperature.
\end{abstract}

Key words : antioxidant effect, anti-inflammatory effect, Red garlic, mRNA expression

\section{서 론}

염증은 외부자극에 대한 생체 조직의 활성화된 면역세포 에 의한 방어반응으로서 면역세포가 세균, 바이러스 및 생 체 이물질 등을 인식하면 활성화되고, 활성화된 면역세포 에서 염증반응의 원인이 되는 많은 인자를 분비하여 유발된 다(1). 염증반응은 병원체의 감염, 화학적 또는 물리적 조직 손상 등으로부터 인체를 보호하기 위해 일어나는 1 차적

*Corresponding author. E-mail : whanbee@hanmail.net Phone : 82-55-860-8947, Fax : 82-55-860-8960

Received 21 March 2017; Revised 29 May 2017; Accepted 29 May 2017.

Copyright (c) The Korean Society of Food Preservation. All rights reserved.
면역반응이지만, 염증반응이 과도해지면 동맥경화증, 류마 티스 관절염, 천식, 기관지염, 다발성 경화증 등을 유발하는 원인이 됨으로 염증반응을 조절할 수 있는 항염증제의 개발 은 다양한 만성 질환을 예방 및 치료하는데 매우 중시 되고 있으며 일부 합성 염증 억제제는 그 효능과 부작용이 확실 히 검증되지 않아 소재를 식물체로부터 개발하기 위한 노력 들이 많이 시도되고 있다(2,3).

마늘(Allium sativum L.)은 다른 약용 식물들과 비교하여 수분 함량은 낮고 황화합물의 함량이 높은데 이들 황화합물 에 기인하는 다양한 기능성으로는 항균활성, 항암, 항혈전 성, 혈압강화작용, 콜레스테롤 저하, 노화방지작용 및 항산 화 활성 등이 알려져 있고(4), 또한 피토케미칼이 풍부하여 ROS(reactive oxygen species)를 제거하고 지질과산화물과 LDL(low density lipoprotein cholesterol) 형성을 억제하며 
항산화 체계를 증대시킨다(5). 마늘의 다양한 생리활성은 염증반응에도 우수한데, 염증반응에서 과발현된 nitric oxide(NO)는 다양한 질환을 유발하여 염증을 심화시고 세 포와 조직손상을 일으켜 만성 염증질환 및 자가 면역질환을 발생시키는데, 여기에 마늘 추출물이 효과가 있다고 알려 져 있으며(6), 마늘의 allicin은 transforming growth factor (TGF)- $\beta 1$, interleukin(IL)-10, IL-10R의 발현을 증가시키며 (7), 황화합물 성분은 $\mathrm{HepG} 2$ 세포의 DNA 손상을 보호하고 (8) 전사인자 nuclear factor-erythroid 2-related factor 2(Nrf2) 의 활성을 통하여 산화적 스트레스에 대항하여 세포 내 redox(reduction-oxidation) 균형을 유지하는 산화 인자인 heme oxygenase-1(HO-1) 등의 증가를 유도하는데, 특히 마 늘 추출물 중 diallyl sulfide(DAS)가 Nrf2 및 MAPK의 활성 촉진하여 HO-1의 발현을 유도한다는 연구결과가 있다(9).

최근 들어 마늘의 매운맛과 냄새를 감소시켜 섭취를 용 이하게 함과 동시에 기능성을 증대시킨 마늘 가공품이 다양 하게 출시되고 있는데, 마늘을 열처리하여 제조한 흑마늘 은 가공 공정 중 페놀 화합물 및 갈변물질 등 유효성분이 생마늘보다 증가되며, 이들 유효성분에 의존적으로 항산화 활성, 체내 지질 저하 및 항비만 활성이 높은 것으로 보고된 바 있다(10). 또 다른 숙성마늘 가공품인 홍마늘은 흑마늘 제조에 소요되는 고온 장기간의 숙성과정을 단축함으로써 붉은 색을 띄며 생마늘보다는 항산화 활성, 체지방 축적 억제 및 지질 저하 작용 등의 생리활성이 높고(11) 담배연기 로 유도된 기관지 염증에 효능을 나타내는 것으로 보고되어 (12) 새로운 마늘 가공품으로 관심이 조명되면서 홍마늘의 항염증 및 다양한 효능에 관한 연구가 진행 중에 있다.

본 연구에서는 홍마늘의 기능성에 기반한 제품개발 연구 의 일환으로 항염증 활성 증강 작용이 있는 천연 식물재료 와 홍마늘의 혼합 추출물을 제조함에 있어 추출온도와 용매 를 달리한 후 이에 대한 유효성분 및 항염증 활성을 분석하 여 가공조건 확립을 위한 기초자료를 확보하고자 하였다.

\section{재료 및 방법}

\section{재 료}

본 실험에 사용한 홍마늘은 (재)남해마늘연구소에서 등 록한 특허(10-1178592, 2012.08.24) 방법으로 $-80^{\circ} \mathrm{C}$ 에서 24 시간 1 차 동결처리 후 상온에서 천천히 해동하여 $60-80^{\circ} \mathrm{C}$ 에 서 58-60시간 동안 숙성시켜 제조하였다. 생약재는 문헌조 사를 통해 항염증활성이 있는 소재인 생강(ginger, Zingiber officinale Roscoe), 도라지(doraji, Platycodon grandiflorum), 모과(quince, Chaenomeles sinensis), 진피(Citrus peel, Citri Pericarpium) 및 박하(Mint, Mentha arvensis)를 선발하였으 며 이들은 진주시 소재 한약재 도매상에서 구입하여 사용하 였다.

\section{시료의 제조}

문헌조사를 통해 선발된 천연식물 소재는 예비실험을 통해 각각을 동량의 무게비로 혼합하여 천연식물 간의 혼합 비를 설정하였으며 이것을 홍마늘과 1:1로 혼합하여 이 시 료 $10 \mathrm{~g}$ 에 물과 에탄올을 각각 $90 \mathrm{~mL}$ 를 첨가하여 각각의 추출물 제조용 시료로 사용하였다. 이때 홍마늘과 천연식 물 재료가 혼합된 시료에 각각의 추출용매(water, ethanol) 을 가하여 $70^{\circ} \mathrm{C}$ 와 $95^{\circ} \mathrm{C}$ 에서 3 시간 동안 추출한 후 여과지 (No. 2, Advantec, Tokyo, Japan)로 여과한 여액을 실험에 사용하였다.

\section{총 페놀 화합물 함량 측정}

총 페놀 화합물의 함량은 페놀성 물질이 phosphomolybdic acid와 반응하여 청색을 나타내는 원리인 Foiln-Denis 방법 (13)을 이용하여 정량하였다. 시료액 $1 \mathrm{~mL}$ 에 FolineCiocalteau 시약(Sigma-Aldrich Co., St. Louis, MO, USA) 및 $10 \% \mathrm{NaCO}_{3}$ 용액(Daejung, Siheung, Gyenggi, Korea)을 각 $1 \mathrm{~mL}$ 씩 차례로 가한 다음 실온에서 1 시간 정치한 후 분광광도계(Libra S 35, Biochrom, Cambridge, England)로 $760 \mathrm{~nm}$ 에서 흡광도를 측정하였다. 표준물질로 gallic acid(Sigma-Aldrich Co.)를 사용하여 시료와 동일한 방법으 로 분석하여 얻은 검량선으로부터 총 페놀 화합물의 함량을 계산하였다.

\section{Alliin 및 S-allyl cysteine(SAC) 함량 측정}

Alliin 함량은 시료를 $0.45 \mu \mathrm{m}$ syringe filter로 여과하여 HPLC-DAD(Agilent 1260 infinity, Agilent, Santa Clara, CA, USA)로 분석하였다. 분석용 칼럼은 syncronis $\mathrm{C}_{18}(3 \times 150$ $\mathrm{mm}, 5 \mu \mathrm{m}$, Thermo scientific, Waltham, MA, USA)를 사용하 였고, 이동상 $\mathrm{A}$ 용액은 $20 \mathrm{mM} \mathrm{Na}_{2} \mathrm{HPO}_{4}$ 와 $10 \mathrm{mM}$ sodium 1-heptanesulfonate 용액을 혼합하여 인산으로 $\mathrm{pH} 2.0$ 으로 조절하였으며, B용액은 methanol:water를 80:20(v/v)의 비 율로 혼합하고 포름산을 이용하여 $\mathrm{pH} 3.0$ 으로 조절 하였다. 이동상의 속도는 $0.4 \mathrm{~mL} / \mathrm{min}$ 으로 하고, $\mathrm{A}$ 용액과 B용액을 시간에 따라 혼합비율을 달리하면서 분석하였다. 컬럼 온 도는 $30^{\circ} \mathrm{C}$, 시료 주입량은 $10 \mu \mathrm{L}$ 로 하였으며, $\mathrm{UV}$ 검출기로 $208 \mathrm{~nm}$ 에서 검출하였다(14).

SAC 함량은 시료를 $0.22 \mu \mathrm{m}$ syringe filter로 여과하여 HPLC-PDA-MS/MS(TSQ Quantum LC-MS/MS, Thermo scientific, Waltham, MA, USA)로 분석하였다. 분석용 칼럼 은 Agilent Zorbax SB-C $\mathrm{C}_{18}(4.6 \times 250 \mathrm{~mm}, 5 \mu \mathrm{m})$ 를 사용하였 고, 이동상 용매는 positive mode에서 이동상 $\mathrm{A}(0.1 \%$ formic acid containing water $)$ 와 $\mathrm{B}(0.1 \%$ formic acid containing acetonitrile)을 시간에 따라 혼합비율을 달리하면서 분석하 였다. 이동상의 속도는 $0.7 \mathrm{~mL} / \mathrm{min}$, 시료 주입량은 $10 \mu \mathrm{L}$, scan type은 SRM mode로 하여 분석을 실시하였다. 


\section{항산화 활성 측정}

$\mathrm{DPPH}(1,1-\mathrm{Diphenyl-2-picrylhydrazyl)}$ 라디칼 소거활성 은 $\mathrm{DPPH}$ 에 대한 전자공여 활성으로 나타낸 것으로 시료액 과 DPPH 용액 $(5 \mathrm{mg} / 100 \mathrm{~mL}$ methanol)을 동량으로 혼합한 다음 실온에서 20 분간 반응시킨 후 분광광도계를 이용하여 $525 \mathrm{~nm}$ 에서 흡광도를 측정하였다(15).

ABTS(2,2-azinobis-(3-ethylbenzo-thiazoline-6-sulphonate) 라디칼 소거활성은 $7 \mathrm{mM}$ 의 ABTS 용액에 potassium persulfate(Sigma-Aldrich Co.)를 $2.4 \mathrm{mM}$ 이 되도록 용해시킨 다음 암실에서 12-16시간 동안 반응시킨 후 $415 \mathrm{~nm}$ 에서 흡광도가 1.5 가 되도록 증류수로 조정한 $\mathrm{ABTS}$ 용액을 사용 하였다. ABTS 용액 $150 \mu \mathrm{L}$ 에 시료액 $50 \mu \mathrm{L}$ 를 혼합하고 실온에서 반응시킨 다음 분광광도계를 이용하여 $415 \mathrm{~nm}$ 에 서 흡광도를 측정하였다(16). DPPH 및 ABTS 라디칼 소거 활성은 시료 무첨가구에 대한 시료첨가구의 흡광도비로 계산하여 \%로 나타내었다.

\section{RAW264.7 대식세포 증식에 대한 세포독성}

실험에 사용된 마우스의 대식세포주인 RAW264.7 세포 는 한국세포주은행(KCLB, Korea)에서 분양받았으며, 세포 배양을 위해 $10 \%$ fetal bovine serum(FBS)과 $1 \%$ penicillinstreptomycin을 포함하는 dulbecco's modified eagle's medium (DMEM) 배지를 사용하였다. 세포는 $\mathrm{CO}_{2}$ incubator $\left(37^{\circ} \mathrm{C}\right.$, $5 \% \mathrm{CO}_{2}$ )에서 배양하였으며 추출물의 세포에 대한 독성 측정은 3-(4,5-dimethylthiazole-2-yl)-2,5-diphenyltetrazolium bromide(MTT) 환원방법을 이용하여 측정하였다. 세포를 96 well-plate에 well당 $5 \times 10^{4}$ 개가 되도록 분주하고 24 시간 부착시킨 후, 추출물들을 각기 일정한 농도로 희석하여 세 포에 처리한 다음 30 분 후 $1 \mu \mathrm{g} / \mathrm{mL}$ 농도의 lipopolysaccharide (LPS, Sigma-Aldrich Co.)를 처리하여 24시간 동안 배양하 였다. 이후 시료를 포함하는 배지를 제거한 후 serum-free 배지와 $5 \mathrm{mg} / \mathrm{mL}$ 농도의 $\mathrm{MTT}$ 용액을 첨가하여 $37^{\circ} \mathrm{C}$ 에서 2 시간 더 배양한 다음 $\mathrm{DMSO}$ 를 분주하여 sonication하고 10 분간 교반한 뒤 $570 \mathrm{~nm}$ 에서 흡광도를 측정해 세포생존율 을 구하였다. 세포생존율은 무처리군에 대한 백분율로 나 타내었다.

RAW264.7 대식세포의 nitric oxide(NO) 생성율 측 정

마우스 대식세포 RAW264.7을 $5 \times 10^{5} \mathrm{cell} / \mathrm{well}$ 의 농도로 24-well plate에 분주하여 24시간 배양한 후 각각의 추출물 을 농도별로 처리하였다. 이것을 30 분 배양한 후에 LPS(1 $\mu \mathrm{g} / \mathrm{mL}$ )를 처리하여 20시간 또는 24시간 배양한 후 세포 상등액을 회수하였다. 회수한 세포 배양 상등액을 원심분 리 $\left(1,000 \mathrm{rpm}, 10 \mathrm{~min}, 4^{\circ} \mathrm{C}\right)$ 한 다음, $50 \mu \mathrm{L}$ 를 취해 sulfanilamide solution $50 \mu \mathrm{L}$ 와 혼합하여 5 분간 빛을 차단하 고 반응시킨 후 $\mathrm{NED}$ solution $50 \mu \mathrm{L}$ 와 혼합하여 상온에서
10 분간 반응시켜, ELISA reader(Epoch, Bioteck, Winooski, $\mathrm{VT}, \mathrm{USA}$ )를 이용하여 $540 \mathrm{~nm}$ 에서 흡광도를 측정하였고, LPS 처리세포군에 대한 상대적인 생성율로 나타내었다.

$\mathrm{DCFH}-\mathrm{DA}$ 에 의한 intracellular reactive oxygen species(ROS) 측정

추출물의 intracellular ROS 측정은 intracellular ROS assay kit(Cell Biolabs, INC, San Diego, CA, USA)을 이용하 여 측정하였다. 96 well black plate에 $5 \times 10^{4}$ cell/well의 RAW264.7 cell을 분주하여 배양 한 후 serum free DMEM 배지로 교환하였다. 다시 세포를 24시간 배양한 후 시료를 농도별로 처리하여 $37^{\circ} \mathrm{C}, 5 \% \mathrm{CO}_{2}$ 조건에서 24 시간 배양하 였다. $\quad \mathrm{PBS}(\mathrm{pH}$ 7.4)로 3회 세척한 후 dichloro-dihydro-fluorescein diacetate(DCFH-DA)를 배지에 $100 \mu \mathrm{L}$ 첨가하여 $37^{\circ} \mathrm{C}, 5 \% \mathrm{CO}_{2}$ 에서 1 시간 배양한 후 또 다시 PBS로 3회 씻어냈다. Lysis buffer $100 \mu \mathrm{L}$ 를 첨가하여 혼합한 후 fluorescence microplate reader(Perkin-Elmer Inc., Waltham, MA, USA)를 이용하여 excitation $485 \mathrm{~nm}$, emisssion $535 \mathrm{~nm}$ 에서 형광을 측정하여 무처리군과 대조군 에 대한 ROS 생성을 비교하여 상대적인 값으로 나타내었 다.

\section{$\mathrm{mRNA}$ 단백질 발현량 측정}

총 RNA는 RAW264.7 세포 $\left(1.0 \times 10^{6}\right.$ cells $\left./ \mathrm{mL}\right)$ 를 24 시간 배양하고 다양한 농도로 조제된 추출물들과 $\mathrm{LPS}(1 \mu \mathrm{g} / \mathrm{mL})$ 를 동시 처리하여 시간별로 배양 한 후 TRI Reagent(MRC Inc., Cincinnati, OH, USA)를 이용하여 분리하였다. 세포에 TRI-reagent를 첨가하여 균질화 한 후, 클로로포름을 첨가 하여 원심분리 $(10,000 \mathrm{rpm}, 10 \mathrm{~min})$ 하였다. 상층액에 동량 의 이소프로판올을 첨가하여 원심분리 $(10,000 \mathrm{rpm}, 8 \mathrm{~min})$ 하여 RNA를 침전시키고 $75 \%$ 의 diethyl pyrocarbonate (DEPC) 처리된 에탄올로 세척한 후, 건조시켜 $\mathrm{DEPC}$ 처리 된 증류수에 녹였다. $260 \mathrm{~nm}$ 의 흡광도를 측정하여 RNA를 정량하였고, A260/A280 nm의 비율이 1.7-1.9 범위 내의 값을 갖는 $\mathrm{RNA}$ 를 실험에 사용하였다. 모든 실험은 RNase-free한 조건하에서 이루어졌다.

cDNA 합성은 RNA to cDNA EcoDry premix(Clontech, Mountain View, CA, USA)를 이용하였고, $1 \mu \mathrm{g}$ 의 total RNA 를 oligo(dT) 18 primer, deoxy-nucleotide tri-phosphate (dNTP, $0.5 \mathrm{M}), 1$ unit RNase inhibitor 그리고 reverse transcriptase(2 Unit)가 섞여있는 premix 에 넣고 $70^{\circ} \mathrm{C}$ 에서 5 분, $37^{\circ} \mathrm{C}$ 에서 5 분, $37^{\circ} \mathrm{C}$ 에서 60 분, 그리고 $70^{\circ} \mathrm{C}$ 에서 10 분간 가열시킴으로서 반응을 중지시켰다. Polymerase chain reaction(PCR)은 합성된 cDNA로부터 iNOS, COX-2, TNF-, $\mathrm{IL}-1 \beta$ 및 $\beta$-actin을 증폭시키기 위하여 $2 \mu \mathrm{L} \mathrm{cDNA}, 4 \mu \mathrm{M}$ 의 5' 과 3' primer, $10 \times \operatorname{buffer}(10 \mathrm{mM}$ Tris- $\mathrm{HCl}, \mathrm{pH} 8.3,50 \mathrm{mM}$ $\mathrm{KCl}, 0.1 \%$ Triton X-100), $250 \mu \mathrm{M} \mathrm{dNTP}, 25 \mathrm{mM} \mathrm{MgCl}_{2}$, 
1 unit Taq polymerase(Promega, Madison, WI, USA)를 섞고 증류수로 최종 $25 \mu \mathrm{L}$ 로 맞춘 다음 $\mathrm{C} 1000$ Thermal Cycler (Bio-Rad, Hercules, CA, USA)를 이용하여 PCR을 실시하였 다. 이때 $\mathrm{PCR}$ 조건은 $94^{\circ} \mathrm{C} 30$ 초, $55^{\circ} \mathrm{C} 30$ 초, $72^{\circ} \mathrm{C} 40$ 초, 35 cycle이며, $\mathrm{PCR}$ 에 의하여 생성된 산물은 RedSafe (INtRON Biotech., Sungnam, Korea)를 넣은 1.2\% agarose gel에서 전기영동을 실시하여 특정 band를 확인하였다.

\section{통계처리}

모든 실험은 3회 이상 반복 실시하였으며 실험으로부터 얻은 결과는 IBM SPSS Statistics 18(IBM, Armonk, NY, $\mathrm{USA})$ 을 사용하여 분석하였다. 결과는 실험군당 평균표준 편차로 표시하였고, 통계적 유의성 검정은 일원배치 분산 분석(one-way analysis of variance)을 한 후 $\mathrm{p}<0.05$ 수준에서 Duncan's multiple range test 및 T-test를 시행하였다.

\section{결과 및 고찰}

\section{총 페놀 화합물 함량}

홍마늘과 천연식물 5종 혼합물을 추출용매 및 온도를 달리하여 추출하여 총 페놀 화합물 함량을 측정한 결과는 Table 1과 같다. 각 추출물 중의 총 페놀 화합물은 E-70이 $608.60 \mathrm{mg} / 100 \mathrm{~g}$ 으로 높았고 다음으로 E-95에서 535.40 $\mathrm{mg} / 100 \mathrm{~g}$ 이었다. 물로 추출한 $\mathrm{W}-70$ 은 $449.15 \mathrm{mg} / 100 \mathrm{~g}$, $\mathrm{W}-95$ 는 $437.63 \mathrm{mg} / 100 \mathrm{~g}$ 으로 두 시료간에는 유의적인 차이 가 없었다. 추출물의 총 페놀 화합물은 물 추출물에 비해 에탄올 추출물에서 더 높게 정량되었고 $95^{\circ} \mathrm{C}$ 추출시에 비해 $70^{\circ} \mathrm{C}$ 에서 추출할 때 그 함량이 더 높았다.

Kwon과 Park(17)의 보고에 따르면 오미자 추출시 물 추 출물에 비해 에탄올 추출물에서 총 페놀 화합물의 함량이 더 높았고, 구릿대 잎 추출물도 물보다는 에탄올에서 더 많은 폴리페놀 화합물이 추출되는 것으로 알려져 있는데 (18), 본 실험에서도 물 추출물 보다는 에탄올 추출물에서 총 페놀 화합물 함량이 더 높아 유사한 경향이었다. 또한 추출온도에 따른 실험결과 $95^{\circ} \mathrm{C}$ 보다 $70^{\circ} \mathrm{C}$ 에서 추출하였을 때 총 페놀 화합물의 함량이 더 높았는데, 이는 인삼을 $85^{\circ} \mathrm{C}$

Table 1. Total polyphenol content of red garlic-supplementary materials extracted by using water and ethanol at $70^{\circ} \mathrm{C}$ and $95^{\circ} \mathrm{C}$

\begin{tabular}{cc}
\hline Samples $^{1)}$ & Total polyphenol contents $(\mathrm{mg} / 100 \mathrm{~g})$ \\
\hline E-70 & $608.60 \pm 7.18^{2)(53)}$ \\
E-95 & $535.40 \pm 7.00^{\mathrm{b}}$ \\
W-70 & $449.15 \pm 14.92^{\mathrm{a}}$ \\
W-95 & $437.63 \pm 5.07^{\mathrm{a}}$ \\
\hline
\end{tabular}

${ }^{1)} \mathrm{E}-70$, extracted by ethanol at $70^{\circ} \mathrm{C}$; E-95, extracted by ethanol at $95^{\circ} \mathrm{C} ; \mathrm{W}-70$, extracted by water at $70^{\circ} \mathrm{C}$; W- 95 , extracted by water at $95^{\circ} \mathrm{C}$.

${ }^{2)}$ Each value represents mean $\pm \mathrm{SD}(\mathrm{n}=3)$.

${ }^{3)-c}$ Means with different superscript in the same column are significantly different at $\mathrm{p}<0.05$.
와 $95^{\circ} \mathrm{C}$ 로 추출한 시료에서 진세노사이드의 총량을 비교한 결과 $85^{\circ} \mathrm{C}$ 에서 추출할 때 $23.5 \mathrm{mg} / \mathrm{g}$ 으로 더 높은 함량이라 고 한 Park 등(19)의 보고와 유사한 경향이었다.

\section{Alliin 및 SAC 함량}

항염증 활성이 있는 홍마늘 복합조성물 중 마늘의 주요 성분인 alliin과 SAC 함량을 측정한 결과(Table 2) alliin 함량 은 추출온도에 따른 통계적인 유의차는 없었으며 추출용매 에 따라 차이가 있었다. 즉 W-70의 alliin 함량은 $1.29 \mathrm{mg} / \mathrm{g}$ 이었고 $\mathrm{W}-95$ 에서는 $1.18 \mathrm{mg} / \mathrm{g}$ 으로 두 시료간에는 유의차 가 없었으나 에탄올로 추출한 E-70 $(0.81 \mathrm{mg} / \mathrm{g})$ 에 비해서는 유의적으로 높은 함량이었다. SAC 또한 alliin의 함량과 동일한 경향으로 에탄올 추출물인 E-70과 E-95에서 각각 1.52 와 $1.98 \mathrm{mg} / \mathrm{g}$ 이 정량된데 반해 W-70과 W-95에서는 각각 2.60 과 $2.34 \mathrm{mg} / \mathrm{g}$ 으로 더 함량이 높았다.

Alliin은 생마늘 중에 존재하는 무취인 수용성 황 함유 아미노산으로 생마늘이 파쇄되면 마늘 중에 존재하는 S-allyl-L-cysteine sulfoxide lyase(alliinase)에 의하여 S-Prop2-en-1-yl prop-2-ene-1-sulfinothioate(allicin)으로 변하지만 (20) alliinase가 불활성화 되었을때에는 alliin으로써 함량이 유지되며, 열이나 산에 안정하여 증숙마늘, 흑마늘 및 초절 임 마늘에서도 존재하며(21), 항암, 고지혈증 감소, 항당뇨, 항산화 효과를 갖는 것으로 알려져 있다(22).

Lee HS 등(23)은 수용성 유황화합물인 SAC는 생마늘에 서의 그 함량이 $30 \mathrm{ppm}$ 정도이며 숙성 마늘에서는 숙성 10 일 및 15 일에 각각 $952 \mathrm{ppm}, 1,140 \mathrm{ppm}$ 으로 증가한다고 보고하였다. 본 연구에서 검출된 SAC도 숙성과정을 거친 홍마늘로부터 유래되어 그 함량이 높으며, 물로 추출할 때 보다 용이하게 추출됨을 알 수 있다.

Table 2. Alliin and SAC content of red garlic-supplementary materials extracted by using water and ethanol at $70^{\circ} \mathrm{C}$ and $95^{\circ} \mathrm{C}$

\begin{tabular}{ccc} 
& & \\
\hline Samples $^{1}$ & Alliin & SAC \\
\hline E-70 & $0.81 \pm 0.13^{2 \text { )a } 3)}$ & $1.52 \pm 0.20^{\mathrm{a}}$ \\
E-95 & $0.85 \pm 0.11^{\mathrm{a}}$ & $1.98 \pm 0.15^{\mathrm{b}}$ \\
W-70 & $1.29 \pm 0.09^{\mathrm{b}}$ & $2.60 \pm 0.32^{\mathrm{c}}$ \\
W-95 & $1.18 \pm 0.03^{\mathrm{b}}$ & $2.34 \pm 0.08^{\mathrm{bc}}$ \\
\hline
\end{tabular}

${ }^{1)} \mathrm{E}-70$, extracted by ethanol at $70^{\circ} \mathrm{C}$; E-95, extracted by ethanol at $95^{\circ} \mathrm{C}$; W-70, extracted by water at $70^{\circ} \mathrm{C}$; W- -95 , extracted by water at $95^{\circ} \mathrm{C}$.

${ }^{2)}$ Each value represents mean \pm SD $(n=3)$.

${ }^{3)-c} \mathrm{Means}$ with different superscript in the same column are significantly different at $\mathrm{p}<0.05$.

\section{항산화 활성}

$\mathrm{DPPH}$ 및 $\mathrm{ABTS}$ 라디칼 소거활성을 통해 항산화 활성을 평가한 결과는 Table 3 과 같다. DPPH 라디칼 소거활성은 E-70이 15.96-73.65\%로 활성이 가장 높았고 다음으로 E-95 
에서 8.40-62.56\%로 활성이 높았다. 물 추출물은 $6.22-$ $47.44 \%$ 의 범위로 에탄올 추출물 보다 활성이 낮았다. 2,500 $\mathrm{\mu g} / \mathrm{mL}$ 농도에서 $\mathrm{DPPH}$ 라디칼 소거활성은 $70^{\circ} \mathrm{C}$ 에서 추출 한 시료의 경우 물 추출물(26.73\%)에 비해 에탄올 추출물 (52.95\%)의 활성이 2 배 이상 높아 라디칼 소거활성은 추출 온도 보다는 추출용매에 따라 활성에 차이가 있었다.

추출용매에 따른 아로니아 추출물의 생리활성을 비교해 본 결과 열수추출물의 경우 $4.99-47.78 \%$ 로 가장 낮은 활성 을 나타내었으며, $50 \%$ 에탄올 및 $50 \%$ 메탄올 추출물이 각각 7.96-70.01\% 및 8.90-69.21\%로 유의적으로 높은 활성 을 나타내었다는 Park 등(24)의 보고는 본 연구의 결과와 동일한 경향이었다. 추출용매를 달리한 무순 추출물의 $\mathrm{DPPH}$ 라디칼 소거능은 물추출물이 $86.67 \%$ 로 활성이 가장 높았고 다음으로 에탄올 추출물과 메탄올 추출물은 유의차 가 없었으며 아세톤 추출물이 $77.23 \%$ 로 활성이 가장 낮았 다는 보고(25)도 있는데, 이들 결과로부터 라디칼 소거활성 은 추출용매의 영향을 받으며, 이는 추출 원료의 특성에 따라 용출되는 유효성분이 서로 상이하기 때문으로 추정된 다.

$\mathrm{ABTS}$ 라디칼 소거활성은 E-70에서 5.71-77.19\%로 가장 높았으며 $5,000 \mathrm{\mu g} / \mathrm{mL}$ 의 농도에서 E-95는 $55.33 \%, \mathrm{~W}-95$ 및 W-70은 42.48과 $37.10 \%$ 였으며 DPPH 라디칼 소거활성 과 동일한 경향이었다. 이처럼 추출용매, 추출온도에 따라 라디칼 소거활성에 차이가 있는 것은 추출조건에 따라 용출 되는 유효성분이 서로 상이하기 때문으로 생각된다.

Kwon 등(26)이 추출용매에 따른 비단풀 추출물의 항산 화 활성비교 연구에 의하면 $\mathrm{ABTS}$ 라디칼 소거활성의 경우 $0.5 \mathrm{mg} / \mathrm{mL}$ 의 농도에서 메탄올 추출물이 $84.83 \%$, 에탄올
추출물이 $75.79 \%$, 물 추출물이 $60.01 \%$ 였는데, 이는 비단풀 추출물의 폴리페놀 함량은 메탄올, 에탄올, 물 추출물에서 각각 $293.25 \mathrm{mg} / \mathrm{g}, 261.27 \mathrm{mg} / \mathrm{g}$ 및 $197.28 \mathrm{mg} / \mathrm{g}$ 으로 차이가 있기 때문이라고 보고되어 있다.

$\mathrm{DPPH}$ 와 $\mathrm{ABTS}$ 라디칼 소거활성은 총 폴리페놀 화합물 의 함량과 양의 상관관계를 나타내는데(27), 본 연구에서도 물 추출물보다 에탄올 추출물에서 총 폴리페놀 함량이 18.2-26.2\% 더 높았고 라디칼 소거활성 또한 에탄올 추출물 에서 더 높았다.

\section{세포독성 및 NO 생성에 대한 억제 활성}

RAW264.7 세포에 홍마늘 복합조성물을 농도별 $(0,120$, 250,500 및 $1,000 \mathrm{\mu g} / \mathrm{mL}$ )로 24시간 동안 처리한 결과(Fig. 1), $1,000 \mu \mathrm{g} / \mathrm{mL}$ 농도까지의 모든 시료에서 생존율은 대조 군 대비 유의성 있는 변화를 나타내지 않았다.

$\mathrm{NO}$ 는 생체 내에서 nitric oxide synthase(NOS)에 의하여 L-arginine으로부터 생성되는 반응성이 강한 자유라디칼이 며, 혈압조절과 신경전달 매개체로 작용하며, 혈액응고, 면 역기능 등의 역할을 하는 것으로 알려져 있는데 $\mathrm{NO}$ 가 필요 이상으로 생성이 되면 염증 반응을 일으키고 조직의 파괴 및 면역 체계의 이상을 나타낸다(28).

LPS를 처리해 염증을 유도한 RAW264.7세포에 홍마늘 복합 추출물을 $125,250,500$ 및 $1,000 \mathrm{\mu g} / \mathrm{mL}$ 농도로 처리 한 후 NO 생성억제 효과를 확인한 결과는 Fig. 2와 같다. $125 \mathrm{\mu g} / \mathrm{mL}$ 처리시는 LPS 단독 처리구에 비해 유의적인 차이를 나타내지 못했으나 그 이상의 농도에서는 농도 의존 적으로 NO 생성이 감소하였다. 물 추출물 보다는 에탄올 추출물의 NO 생성 억제 활성이 더 높았으며, E-70 보다는

Table 3. DPPH and ABTS radical scavenging activity of red garlic-supplementary materials extracted by using water and ethanol at $70^{\circ} \mathrm{C}$ and $95^{\circ} \mathrm{C}$

\begin{tabular}{|c|c|c|c|c|c|}
\hline \multirow{2}{*}{ Radical } & \multirow{2}{*}{$\begin{array}{c}\text { Concentration } \\
(\mu \mathrm{g} / \mathrm{mL})\end{array}$} & \multicolumn{4}{|c|}{ Sample code ${ }^{1)}$} \\
\hline & & E-70 & E-95 & W-70 & W-95 \\
\hline \multirow{5}{*}{ DPPH } & 313 & $15.96 \pm 0.19^{22 \mathrm{a} 33)(4)}$ & $8.40 \pm 0.96^{\mathrm{aB}}$ & $6.22 \pm 1.09^{\mathrm{aA}}$ & $6.41 \pm 0.02^{\mathrm{aA}}$ \\
\hline & 625 & $18.91 \pm 0.96^{6 \mathrm{D}}$ & $15.38 \pm 0.13^{\mathrm{bC}}$ & $10.26 \pm 0.51^{\mathrm{bB}}$ & $8.59 \pm 0.51^{\mathrm{bA}}$ \\
\hline & 1,250 & $29.68 \pm 0.32^{\mathrm{cD}}$ & $22.95 \pm 0.77^{\mathrm{cC}}$ & $17.88 \pm 0.06^{\mathrm{CB}}$ & $15.06 \pm 0.19^{\mathrm{cA}}$ \\
\hline & 2,500 & $52.95 \pm 0.26^{\mathrm{dC}}$ & $36.35 \pm 0.06^{\mathrm{dB}}$ & $26.73 \pm 1.47^{\mathrm{dA}}$ & $27.63 \pm 0.06^{\mathrm{dA}}$ \\
\hline & 5,000 & $73.65 \pm 0.45^{\mathrm{eD}}$ & $62.56 \pm 0.05^{\mathrm{eC}}$ & $45.64 \pm 0.13^{\mathrm{eA}}$ & $47.44 \pm 0.38^{\mathrm{eB}}$ \\
\hline \multirow{5}{*}{ ABTS } & 313 & $5.71 \pm 0.10^{\mathrm{aD}}$ & $3.62 \pm 0.10^{\mathrm{aC}}$ & $2.24 \pm 0.14^{\mathrm{aA}}$ & $2.62 \pm 0.05^{\mathrm{aB}}$ \\
\hline & 625 & $10.29 \pm 0.10^{\mathrm{bD}}$ & $6.48 \pm 0.29^{\mathrm{aC}}$ & $4.43 \pm 0.05^{\mathrm{bA}}$ & $5.38 \pm 0.33^{\mathrm{bB}}$ \\
\hline & 1,250 & $21.19 \pm 0.24^{\mathrm{cD}}$ & $14.19 \pm 0.67^{\mathrm{bC}}$ & $9.24 \pm 0.86^{\mathrm{cA}}$ & $11.38 \pm 0.24^{\mathrm{cB}}$ \\
\hline & 2,500 & $40.90 \pm 1.00^{\mathrm{dC}}$ & $28.14 \pm 0.90^{\mathrm{cC}}$ & $19.67 \pm 0.24^{\mathrm{dA}}$ & $22.19 \pm 0.48^{\mathrm{dB}}$ \\
\hline & 5,000 & $77.19 \pm 0.43^{\mathrm{eD}}$ & $55.33 \pm 1.62^{\mathrm{dC}}$ & $37.10 \pm 0.14^{\mathrm{eA}}$ & $42.48 \pm 0.29^{\mathrm{eB}}$ \\
\hline
\end{tabular}

\footnotetext{
${ }^{1)} \mathrm{E}-70$, extracted by ethanol at $70^{\circ} \mathrm{C}$; E-95, extracted by ethanol at $95^{\circ} \mathrm{C} ; \mathrm{W}-70$, extracted by water at $70^{\circ} \mathrm{C} ; \mathrm{W}-95$, extracted by water at $95^{\circ} \mathrm{C}$.

${ }^{2)} \mathrm{Each}$ value represents mean \pm SD $(\mathrm{n}=3)$.

${ }^{3) a-e}$ Means with different superscript in the same column are significantly different at $p<0.05$.

${ }^{4) A-D}$ Means with different superscript in the same row are significantly different at $p<0.05$.
} 


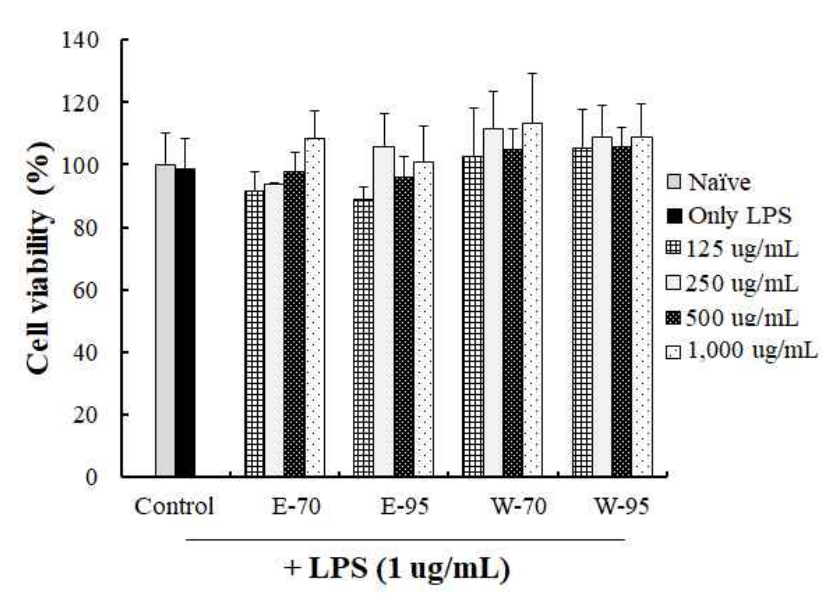

Fig. 1. Effects of red garlic-supplementary materials extracted by using water and ethanol at $70^{\circ} \mathrm{C}$ and $95^{\circ} \mathrm{C}$ on the cell viability in RAW264.7 cells.

E-70, extracted by ethanol at $70^{\circ} \mathrm{C}$; E-95, extracted by ethanol at $95^{\circ} \mathrm{C}$; W-70, extracted by water at $70^{\circ} \mathrm{C}$; W- 95 , extracted by water at $95^{\circ} \mathrm{C}$.

After Raw264.7 cells were pre-treated with LPS for $30 \mathrm{~min}$, it were treated with the indicated concentrations $(0,125,250,500$ and $1,000 \mu \mathrm{g} / \mathrm{mL})$ of extracts for $24 \mathrm{~h}$. Cell viability was evaluated using a colorimetric assay based on MTT assay.

Data represent the mean $\pm \mathrm{SD}$ of three independent experiments.

\section{E-95 활성이 더 높았다.}

Koh 등(29)은 추출 온도를 달리한 민들레 잎의 열수추출 물의 NO 생성 저해능은 추출 온도가 낮을수록 더 활성이 높아져 민들레 잎에 함유된 항염증 활성물질이 열에 상당히 민감하다고 하였는데, 본 연구의 결과에서는 $70^{\circ} \mathrm{C}$ 보다 9 $5{ }^{\circ} \mathrm{C}$ 에서 추출하였을 때 $\mathrm{NO}$ 생성억제율이 더 높아 상이한 결과였다. 이러한 차이는 길경, 황기 및 오미자 추출물의 $\mathrm{NO}$ 생성 억제 활성은 서로 상이하여 황기는 $30^{\circ} \mathrm{C}$, 오미자는

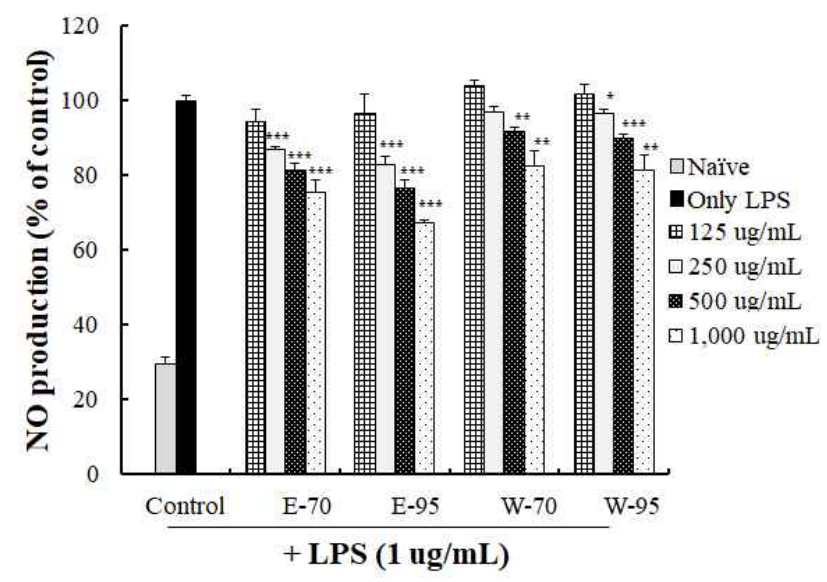

Fig. 2. Effects of red garlic-supplementary materials extracted by using water and ethanol at $70^{\circ} \mathrm{C}$ and $95^{\circ} \mathrm{C}$ on the production of $\mathrm{NO}$ on RAW264.7 cells.

E-70, extracted by ethanol at $70^{\circ} \mathrm{C}$; E-95, extracted by ethanol at $95^{\circ} \mathrm{C}$; W-70, extracted by water at $70^{\circ} \mathrm{C}$; W-95, extracted by water at $95^{\circ} \mathrm{C}$.

The results are mean $\pm S D$ of triplicates from a representative experiment. Statistically significant value was calculated by compared with control group by student's t-test $\left(*, \mathrm{p}<0.05 ;{ }^{* *}, \mathrm{p}<0.01 ; * * *, \mathrm{p}<0.001\right)$. $20-30^{\circ} \mathrm{C}$ 에서 추출하였을 때 가장 효과적이었으나 길경은 추출온도에 영향을 받지 않아 소재에 따라 유효성분이 추출 되는 조건이 서로 상이하다는 Kang 등(30)의 보고로 미루어 볼 때 원료들의 특성에 기인하는 것으로 추정된다. 또한 마늘의 주요 유효성분인 alliin 및 SAC를 포함한 수용성 황화합물들이 비교적 열에 안정하며, 이들이 복합적으로 영향을 미쳤기 때문으로 생각된다.

Reactive oxygen species(ROS) 생성 억제 효과

추출조건을 달리하여 제조한 홍마늘 복합조성물의 ROS 생성억제 효능은 대식세포에 시료를 농도별로 처리하고 LPS로 세포 내 염증반응을 유도하여 확인하였다(Fig. 3). $1,000 \mu \mathrm{g} / \mathrm{mL}$ 농도에서 LPS 단독처리시 ROS 생성율에 비해 E-70 처리시 $72.37 \%$ 의 생성율을 보였고, E-95은 $64.92 \%$, 물 추출물은 W-70은 $79.46 \%, \mathrm{~W}-95$ 는 $84.23 \%$ 를 나타내어 E-95의 ROS 생성 억제 효과가 가장 높았다.

추출방법에 따른 육미지황탕의 ROS 생성율을 측정한 결과 $200 \mathrm{\mu g} / \mathrm{mL}$ 의 농도에서 대조군에 비해 물추출물은 $22.3 \%$, 에탄올 추출물은 $53.8 \%$ 감소하여 물 추출물 보다는 에탄올 추출물에서 효능이 있었다는 Lee 등(31)의 보고는 본 연구 결과와 일치하는 경향이었다.

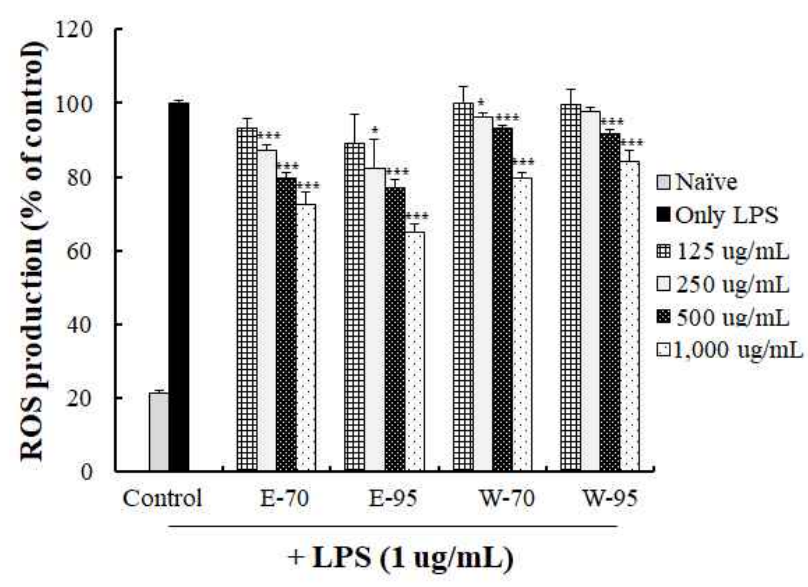

Fig 3. Effects of red garlic-supplementary materials extracted by using water and ethanol at $70^{\circ} \mathrm{C}$ and $95^{\circ} \mathrm{C}$ on the production of ROS on RAW264.7 cells.

E-70, extracted by ethanol at $70^{\circ} \mathrm{C}$; E-95, extracted by ethanol at $95^{\circ} \mathrm{C} ; \mathrm{W}-70$, extracted by water at $70^{\circ} \mathrm{C} ; \mathrm{W}-95$, extracted by water at $95^{\circ} \mathrm{C}$.

The results are mean $\pm \mathrm{SD}$ of triplicates from a representative experiment. Statistically significant value was calculated by compared with control group by student's t-test $\left(*, \mathrm{p}<0.05 ;{ }^{* *}, \mathrm{p}<0.01 ; * * *, \mathrm{p}<0.001\right)$.

\section{염증성 cytokines}

염증 반응에 관여하는 주요 세포는 macrophage로 알려져 있으며, 여러 자극이나 면역세포들이 분비하는 사이토카인 등에 의해 활성화 되어, 염증 반응을 유발하고, 염증 부위로 면역 세포의 이동을 촉진시킨다(32). 대식세포는 염증 유발 물질 LPS에 의해 COX-2, prostaglandin E2(PGE2), iNOS 
및 $\mathrm{NO}$ 의 생성이 증가되고 염증성 cytokine인 tumor necrosis factor(TNF)- $a, \mathrm{IL}-1, \mathrm{IL}-6$ 분비가 증가된다고 알려져 있다 (33).

홍마늘 복합조성물의 물과 에탄올 추출물의 NO 및 ROS 생성 억제효과를 살펴본 결과 물 추출물보다는 에탄올 추출
물에서 활성이 더 높아 염증성 cytokines 측정은 에탄올 추출물을 대상으로 실시하였다. RAW264.7 세포에 LPS를 처리한 후, 홍마늘 조성물을 $70^{\circ} \mathrm{C}$ 와 $95^{\circ} \mathrm{C}$ 에서 에탄올로 추 출한 추출물을 500 과 $1,000 \mathrm{\mu g} / \mathrm{mL}$ 농도로 처리하여 RT-PCR 방법으로 유전자 발현량을 측정하였다. 그 결과
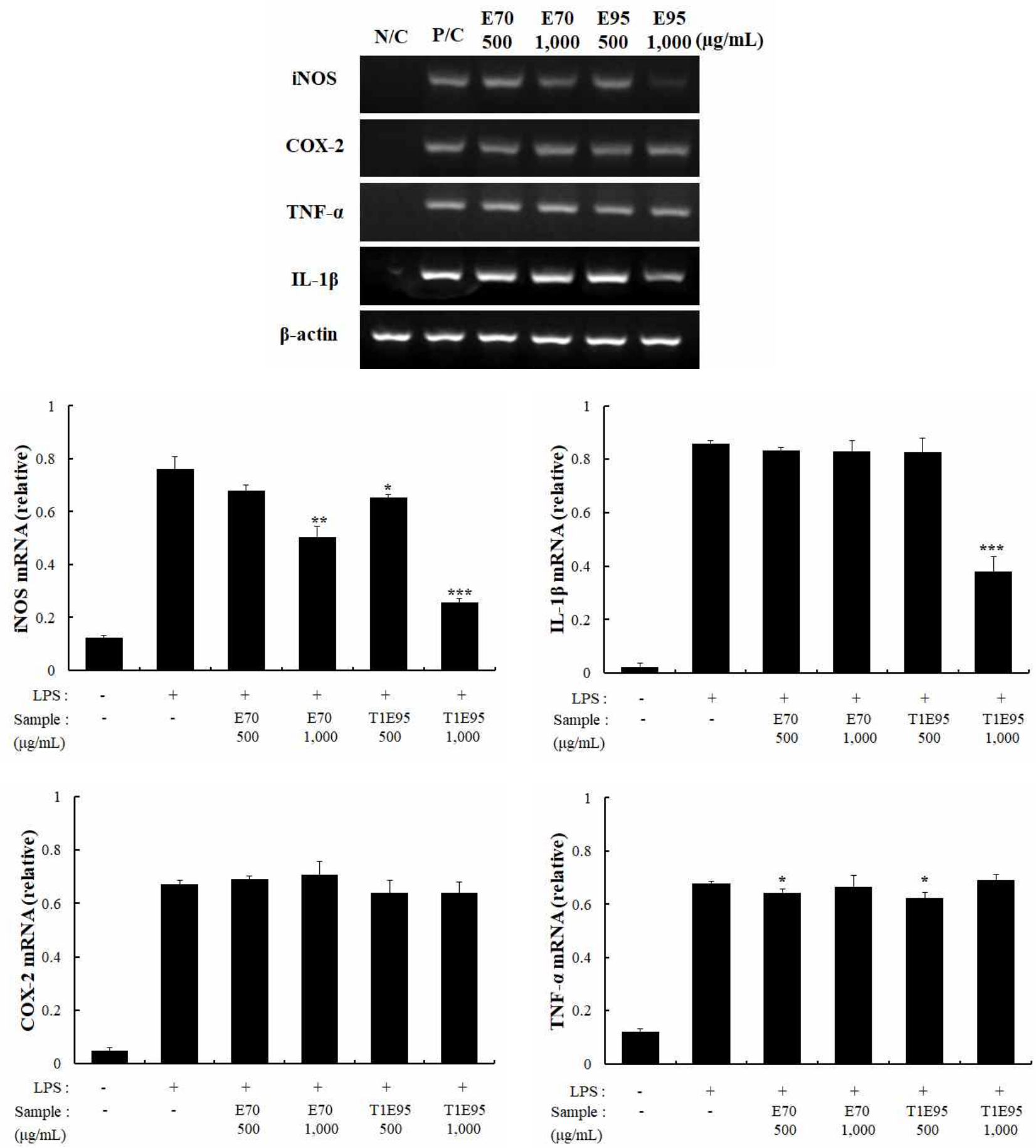

Fig. 4. Inhibitory effects of red garlic-supplementary materials extracts on the mRNA expression of iNOS, COX-2, TNF- $a$, and IL-1ß in RAW264.7 cells. E-70, extracted by ethanol at $70^{\circ} \mathrm{C}$; E-95, extracted by ethanol at $95^{\circ} \mathrm{C}$; W-70, extracted by water at $70^{\circ} \mathrm{C}$; W-95, extracted by water at $95^{\circ} \mathrm{C}$.

RAW264.7 cells were treated with the indicated concentrations of T1-mixture extracts $(500,1,000 \mu \mathrm{g} / \mathrm{mL})$ in the presence or absence of LPS $(1 \mu \mathrm{g} / \mathrm{mL})$ for $24 \mathrm{~h}$.

Data are represented as means \pm SD. Statistically significant value was calculated by compared with control group by student's $\mathrm{t}$-test $\left({ }^{*}, \mathrm{p}<0.05 ;{ }^{* *}, \mathrm{p}<0.01 ;{ }^{* *}, \mathrm{p}<0.001\right)$. 
Fig. 4에서와 같이 cytokine의 종류에 따라 서로 다른 발현 양상이 확인되었는데 $1,000 \mathrm{\mu g} / \mathrm{mL}$ 농도로 처리하였을 때 E-95는 iNOS와 IL- $1 \beta$ 의 발현량이 LPS 단독처리 대조군 대비 유의성 있게 감소하였고 반면 E-70은 iNOS를 제외하 고는 발현량에 영향을 미치지 않았다. 이러한 결과로 볼 때 추출시 추출온도에 따라 RAW264.7 세포에서 염증 매개 성 cytokine을 억제하는 활성은 서로 상이 할 것으로 추측된다. 흑마늘 추출물을 소재로 한 연구에서 TNF- $\mathrm{a}, \mathrm{IL}-2$ 와 같은 사이토카인의 생성이 유도되어 자연면역에 의한 $\mathrm{T}$ 림프구 의 생성인자로 작용하며, 한편으로는 $\mathrm{IL}-4, \mathrm{IL}-6, \mathrm{IL}-10$ 과 같은 사이토카인의 생성으로 B 림프구의 활성화를 통한 면역증진에 기여한다는 보고가 있다(34). 홍마늘이 $50 \%$ 이상 함유된 생약재 복합조성물은 추출온도에 따라 활성정 도에는 차이가 있지만 염증 매개인자의 활성을 감소시켰으 며 특히 E-95는 iNOS 및 IL-1ß의 발현량을 감소시켜 항염증 효과가 있을 것으로 기대된다.

\section{요 약}

홍마늘과 생약재 5종(생강, 도라지, 모과, 진피, 박하)이 혼합된 조성물의 항염증 활성을 검증하고자 홍마늘 $50 \%$ 와 천연식물류 5 종을 각각 $10 \%$ 씩 혼합한 조성물을 물과 에탄 올로 $70^{\circ} \mathrm{C}$ 및 $95^{\circ} \mathrm{C}$ 에서 3 시간 동안 추출하여 각각의 추출물 을 제조하였다. 총 페놀화합물은 $70^{\circ} \mathrm{C}$ 에서 에탄올로 추출 시 $608.60 \mathrm{mg} / 100 \mathrm{~g}$ 으로 가장 높은 함량이었으며 물 추출물 에서는 이보다 낮은 함량이었다. 홍마늘의 유효성분인 alliin과 SAC는 $70^{\circ} \mathrm{C}$ 에서 물로 추출하였을 때 각각 1.29 $\mathrm{mg} / \mathrm{g}$ 과 $2.60 \mathrm{mg} / \mathrm{g}$ 으로 에탄올 추출물에 비해 유의적으로 높은 함량이었다. 홍마늘과 5종 천연식물류 복합추출물의 $\mathrm{DPPH}$ 와 $\mathrm{ABTS}$ 라디칼 소거활성은 $70^{\circ} \mathrm{C}$ 에서 에탄올로 추 출하였을 때 각각 15.96-73.65\%와 5.71-77.19\%로 가장 높았 다. NO 생성억제 활성은 물 추출물 보다는 에탄올 추출물에 서 더 높았으며 $70^{\circ} \mathrm{C}$ 보다는 $95^{\circ} \mathrm{C}$ 에서 추출하였을 때 더 활성이 높았다. $\operatorname{ROS}$ 생성은 에탄올 $95^{\circ} \mathrm{C}$ 추출물이 1,000 $\mu \mathrm{g} / \mathrm{mL}$ 농도에서 대조군 대비 약 $64.92 \%$ 로 가장 활성이 높았다. iNOS와 IL- $1 \beta$ 의 발현량은 $1,000 \mu \mathrm{g} / \mathrm{mL}$ 농도의 9 $5^{\circ} \mathrm{C}$ 에탄올 추출물에서 LPS 단독처리군에 비해 유의적으 로 감소되었다. 이상의 결과를 종합하여 볼 때 홍마늘 및 생약재 복합 추출물의 항산화와 항염증 활성은 서로 다른 유용물질의 영향으로 발현이 되며, 이들 유용물질은 추출 용매와 온도에 따라 함량이나 구성이 서로 상이하였다.

\section{References}

1. Zamora R, Vodovotz Y, Billiar TR (2000) Inducible nitric oxide synthase and inflammatory diseases. Mol Med, 6, 347-373

2. Kaplanski G, Marin V, Montero-Julian F, Mantovani A, Farnarier C (2003) IL-6: a regulator of the transition from neutrophil to monocyte recruitment during inflammation. Trends Immunol, 24, 25-29

3. Bae HJ, Chun HJ (2002) Changes in volatile sulfur compounds of garlic under various cooking conditions. Korean J Food Cook Sci, 18, 365-371

4. Iciek M, Kwiecien I, Wlodek L (2009) Biological properties of garlic and garlic-derived organosulfur compounds. Environ Mol Mutagen, 50, 247-265

5. Jang HR (2012) Antibiotic effect for acne germs and antioxidant activities of Allium sativum L. peel extract. MS Thesis, Seokyeong University, Korea, p 3

6. Shin JH, Choi DJ, Lee SJ, Cha JY, Kim JG, Sung NJ (2008) Changes of physicochemical components and antioxidant activity of garlic during its processing. J Life Sci, 18, 1123-1131

7. Park RS (2002) Effects of allicin on cytokine production genes of human peripheral blood mononuclear cells. Korean J Food Nutr, 15, 191-196

8. Belloir C, Singh V, Daurat C, Siess MH, Le Bon AM (2006) Protective effects of garlic sulfur compounds against DNA damage induced by direct- and indirect-acting genotoxic agents in HepG2 cells. Food Chem Toxicol, 44, 827-834

9. Chen C, Pung D. Leong V, Hebbar, V, Shen G, Nair S, Li W, Kong AN (2004) Induction of detoxifying enzymes by garlic organosulfur compounds through transcription factor Nrf2: effect of chemical structure and stress signals. Free Radic Biol Med 37, 1578-1590

10. Kim RJ, Lee SJ, Kim MJ, Hwang CR, Kang JR, Jung WJ, Sung NJ (2010) Effects of fresh, red and black garlic powder on lipid metabolism of obese rats induced by high fat diet. J Agric Life Sci, 44, 159-170

11. Lee SJ, Kim RJ, Ryu JH, Shin JH, Kang MJ, Kim IS, Sung NJ (2011) Effects of the Red garlic extract for anti-obesity and hypolipidemic in obese rats induced high fat diet. J Life Sci, 21, 211-220

12. Jeong YY, Park HJ, Cho YW, Kim EJ, Kim GT, Mun YJ, Lee JD, Shin JH, Sung NJ, Kang DW, Han JH (2012) Aged red garlic extract reduces cigarette smoke extract induced cell death in human bronchial smooth muscle cells by increasing intracellular glutathione levels. Phytother res, 26, 18-25

13. Folin O, Denis W (1915) A colorimetric method for the 
determination of phenols (and phenol derivatives) in urine. J Biol Chem, 22, 305-308

14. Korea health functional foods (2015) Korea Health Supplement Association, p 630

15. Blois MS (1958) Antioxidant determination by the use of a stable free radical. Nature, 181, 1199-1200

16. Re R, Pellegrini N, Proteggente A, Pannala A, Yang M, Rice-Evans C (1999) Antioxidant activity applying an improved ABTS radical cation decolorization assay. Free Radic Biol Med, 26, 1231-1237

17. Kwon HJ, Park CS (2008) Biological activities of extracts from Omija (Schizandra chinensis Baillon). Korean J Food Preserv, 15, 587-592

18. Lee YS (2007) Antioxidative and physiological activity of extracts of Angelica dahurica leaves. Korean J Food Preserv, 14, 78-86

19. Park KH, Kim YS, Jeong JH (2011) Inhibitory effects of ginseng extracts on histamine-release from rat's mast cell. Korean J Plant Res, 24, 98-104

20. Jeong DH, Kim KBWR, Kang BK, Jung SA, Kim HJ, Jeong HY, Bark SW, Ahn DH (2012) Anti-inflammatory activity of the Undaria pinnatifida water extract. J Appl Biol Chem, 55, 221-225

21. Lee SY, Nam SH, Lee HJ, Son SE, Lee HJ (2015) Antibacterial activity of aqueous garlic extract against Escherichia coli 0157:H7, Salmonella typhimurium and Staphylococcus aureus. J Fd Hyg Safety, 30, 210-216

22. Sangeetha T, Darlin QS (2007) Preventive effect of S-allyl cysteine sulfoxide (alliin) on lysosomal hydrolases and membrane-bound ATPases in isoproterenol-induced myocardial infarction in Wistar rats. J Biochem Mol Toxicol, 21, 118-124

23. Lee HS, Yang ST, Ryu BH (2011) Effects of aged black garlic extract on lipid improvement in rats fed with high fat-cholesterol diet. J Life Sci. 21, 884-892

24. Park HM, Hong JH (2014) Physiological activities of Aronia melanocarpa extracts on extraction solvents. Korean J Food Preserv, 21, 718-726

25. Han JH, Moon HK, Chung SK, Kang WW (2013) Comparison of antioxidant activities of radish bud (Raphanus sativus L.) according to extraction solvents and sprouting period. J Korean Soc Food Sci Nutr, 42, 1767-1775

26. Kwon YR, Lee HR, Hwang SH, Kwon OJ, Youn KS (2016) Antioxidant activities and physiological properties of Euphorbia humifusa extracts prepared using different solvents. Korean J Food Preserv, 23, 252-258

27. In JP, Shin JM, Hur SJ, Lee SK (2014) Antioxidative, antimicrobial and anticytotoxic activities of seungmagalgeuntang and fermented seungmagalgeuntang. J Korean Soc Food Sci Nutr, 43, 980-988

28. Seo WG, Pae HO, Oh GS, Kim NY, Kwon TO, Shin MK, Chai KY, Chung HT (2001) The aqueous extract of Rhodiola sachalinensis root enhances the expression of inducible nitric oxide synthase gene in RAW264.7 macrophages. J Ethnopharmacol, 76, 119-123

29. Koh YJ, Park YK, Park Kim YS, Cha DS, Choi, HD (2009) Preparation of hot water extracts of dandelion leaves to increase anti-inflammatory activity. J Korean Soc Food Sci Nutr, 38, 391-395

30. Kang CH, Kwak DY, So JS (2013) Inhibition of nitric oxide production and hyaluronidase activities from the combined extracts of Platycodon grandiflorum, Astragalus membranaceus, and Schisandra chinensis. J Korean Soc Food Sci Nutr, 42, 844-850

31. Lee GH, Yoo DY (2012) Evaluation of anti-Inflammatory effects of Yukmijihwangtang and individual drug substances based on the extraction methods. J Korean Obstet Gynecol, 25, 85-107

32. Lee ES, Ju HK, Moon TC, Lee E, Jahng Y, Lee SH (2004) Inhibition of nitric oxide and tumor necrosis factor- $a$ (TNF- $a$ ) production by propenone compound through block ade of nuclear factor (NF)-kappa bactivation in cultured murine macrophages. Biol Pharm Bull, 27, 617-620

33. Hinz B, Brune K (2002) Cyclooxygenase-2-10 years later. J Pharmacol Exp Ther, 300, 367-375

34. Seo MJ, Kang BW, Park JU, Kim MJ, Lee HH, Ryu EJ, Joo WH, Kim KH, Jeong YK (2013) Effect of black garlic extract on cytokine generation of mouse spleen cells. J Life Sci, 23, 63-68 